\title{
Establishing a relationship between endometrial cytology and uterine fluid, followed by evaluation of their association with fertility parameters in post-partum dairy cows
}

\author{
Akshay Sharma*, and Madhumeet Singh \\ Department of Veterinary Gynecology and Obstetrics, College of Veterinary and Animal Sciences, CSKHPKV, \\ Palampur, India
}

\begin{abstract}
SHARMA, A., M. SINGH: Establishing a relationship between endometrial cytology and uterine fluid, followed by evaluation of their association with fertility parameters in post-partum dairy cows. Vet. arhiv 89, 435-446, 2019.
\end{abstract}

\section{ABSTRACT}

The objectives of this study were to investigate the relationship between uterine fluid and endometrial cytology (EC) followed by study of association with uterine involution, calving to first ovulation interval, and conception in dairy cows. On day 43 post-partum, 23 dairy cows were grouped, on the basis of EC, as having low $(<10 \%)$ or high $(>10 \%)$ polymorphonuclear cells $(\mathrm{PMN})$, and the quantity of uterine fluid was assessed by ultrasound. Uterine involution was significantly earlier in cows having low PMNs as compared to high PMNs (24.1 vs. 31.7 d). The interval from calving to first ovulation was significantly shorter in low as compared to high PMN cows (23.4 vs. 30.7 d). With the increase in the quantity of uterine fluid, PMNs also increased from $6 \%$ to $21 \%$. The mean interval from calving to ovulation was longer in primiparous cows with high PMN (33 d) compared to that of primiparous and multiparous cows with low PMN (24 and $22 \mathrm{~d}$, respectively). Cows that had uterine fluid on day 43 post-partum had fewer days open than those with no uterine fluid (107 vs. $130 \mathrm{~d})$. So, the conclusion may be drawn that transrectal ultrasonography and endometrial cytology, when combined together, on day 43 post-partum, have diagnostic value in the assessment of uterine inflammation.

Key words: endometrial cytology; fertility; polymorphonuclear cells; transrectal ultrasonography; uterine fluid

\section{Introduction}

After parturition in dairy cows, fertility is considered to be the principal economic factor on milk producing farms, and any alteration or extension to this phase results in progressive economic loss (PATEL et al., 2006). This may be due to bacterial

\footnotetext{
*Corresponding author:

Akshay Sharma, PhD Scholar, Department of Veterinary Gynecology and Obstetrics, College of Veterinary and Animal Sciences, CSKHPKV, Palampur, India, E-mail: akshays482@gmail.com
} 
A. Sharma and M. Singh: Establishing a relationship between endometrial cytology and uterine fluid in post-partum dairy cows

contamination of the uterus during the early post-partum period. Eighty to $100 \%$ of cows are found to have bacterial contamination of the uterus in the first 2 weeks post-partum (FOLDI et al., 2006). During the post-partum period, uterine contamination affects the resumption of ovarian follicular growth and function, and eventually disturbs ovulation in cattle (OPSOMER et al., 2000). During a sub-clinical or clinical inflammation, the primary uterine response to infection is intensive migration of polymorphonuclear cells (PMN) into the lumen, that reach up to $90 \%$ relative to endometrial cells (KLUCINSKI et al., 1990). The presence of neutrophils in the lumen, therefore, is an excellent indication of an active inflammatory process (BUTT et al., 1993). The cytobrush technique has been used to diagnose sub-clinical endometritis (SCE) and, thus, to evaluate the relationship between PMNs and conception (BARLUND et al., 2008). The severity of the uterine inflammation may be assessed by studying the relative proportion of PMNs to endometrial cells in the post-partum bovine uterus. Although some researchers have reported the relationship between uterine inflammation and interval from calving to onset of cyclicity (SENOSY et al., 2009) and first insemination or pregnancy (LE BLANC et al., 2002), the relationship between endometrial cytology and ultrasonographic confirmation of the calving to ovulation interval is not yet known (DOUREY et al., 2011). Therefore, the primary objective of this study was to investigate the relationship between uterine fluid and endometrial cytology. The secondary objective was determination of the relationship of uterine involution, the interval from calving to first ovulation and subsequent conception with endometrial cytology (EC) and uterine fluid in post-partum dairy cows.

\section{Materials and methods}

Animals. Twenty-three (10 primiparous, 13 multiparous) lactating Jersey cows at the University Dairy Farm, Himachal Pradesh Agricultural University, Palampur $\left(32.6^{\circ} \mathrm{N}, 76.3^{\circ} \mathrm{E}\right.$, altitude $\left.1290.8 \mathrm{~m}\right)$ were enrolled for the cytological study. The cows were reared in a loose housing system under standard management conditions, fed a total mixed ration, once daily ad libitum, and had unrestricted access to water. The cows were milked twice daily (04:00 and 15:00 h).

Ultrasonography and endometrial cytology. Transrectal ultrasonography (TRUS) was performed to assess the uterine involution and ovarian rebound, using a linear transducer, frequency 7.5 MHz (Sonosite M turbo; Sonosite India Pvt. Ltd.), at weekly intervals from 8 days after calving to a maximum of 43 days post-partum. Ovulation was confirmed when a large follicle, present on one ultrasound observation, had disappeared and a corpus luteum had appeared at the same relative location on the ovary during the following observation. Uterine involution was considered complete when both gravid and non-gravid horns were nearly symmetrical and no further 
change took place between two consecutive examinations in the diameter of the horns or cervix (ABDEL-KHALEK et al., 2013). Endometrial cytology was done (on day 43 postpartum) by passing a stainless steel tube (covered with a plastic sleeve to avoid contamination) through the vagina to the external os of the cervix. The plastic sleeve was perforated and the stainless steel sheath and extension was manipulated through the cervix and into the body of the uterus, where the cytobrush was turned approximately a $1 / 4$ turn clockwise to obtain endometrial cells from the uterus. The cytobrush was rolled onto a clean glass slide and fixed with alcohol (70\%), followed by staining with a modified Wright-Giemsa stain for 45 mins and evaluation was done using $\times 400$ magnification. A differential count, a minimum of 100 cells (endometrial, PMNs and epithelial cells; Fig. 1-2), was performed to provide a quantitative assessment of endometrial inflammation (BARLUND et al., 2008). The reason for performing endometrial cytology on day 43 was to make the association between endometrial inflammation and the presence of uterine fluid.

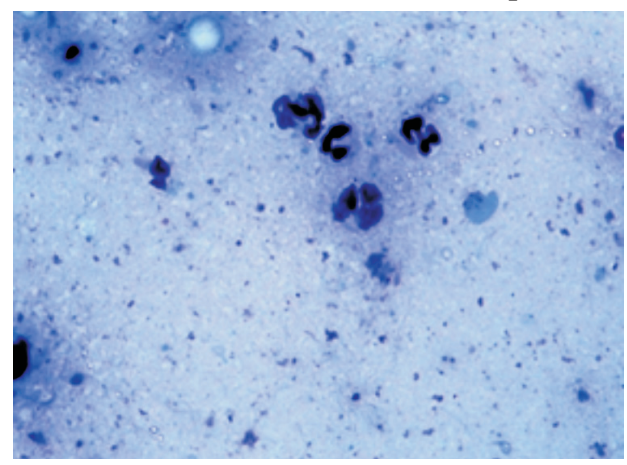

Fig. 1. Image showing PMN cells

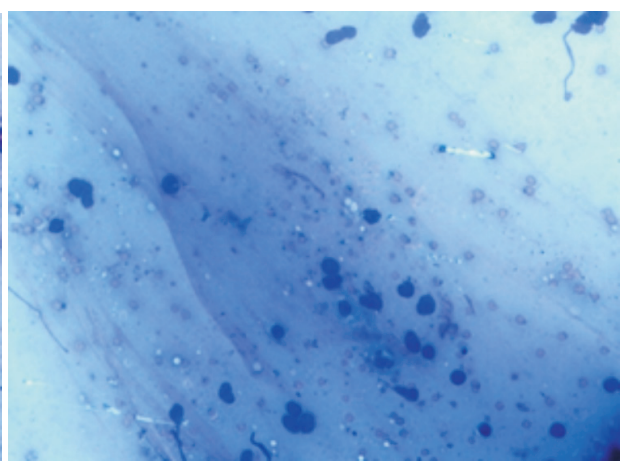

Fig. 2. Image showing endometrial cells (dark blue) and epithelial cells (light purple)

The presence of uterine fluid was determined by transrectal ultrasonography on day 43 post-partum. Measurements of uterine lumen were made in at least three locations, and the point where the maximum amount of fluid was present was taken into consideration (DOUREY et al., 2011). Also, the uterine horn diameter and endometrial thickness were measured. Using the lumen diameter as an indirect measure of uterine fluid, the cows were divided into three groups: no fluid $(<1 \mathrm{~mm})$, a small volume of fluid $(1-5 \mathrm{~mm})$, or a large volume of fluid (5-10 mm) (Fig. 3-5). On the basis of the relative proportion of PMN, the cows were divided into two groups: low PMN $(<10 \%)$ and high PMN $(>10 \%)$, as described by KASIMANICKAM et al. (2004). Cows with high PMN were considered to have sub-clinical endometritis. All the cows were inseminated at first behavioral estrus post-partum and pregnancy diagnosis was performed by transrectal ultrasonography of 
A. Sharma and M. Singh: Establishing a relationship between endometrial cytology and uterine fluid in post-partum dairy cows

the uterus $32 \mathrm{~d}$ after timed AI (Fig. 6). Cows determined to be non-pregnant were again inseminated up to three times.

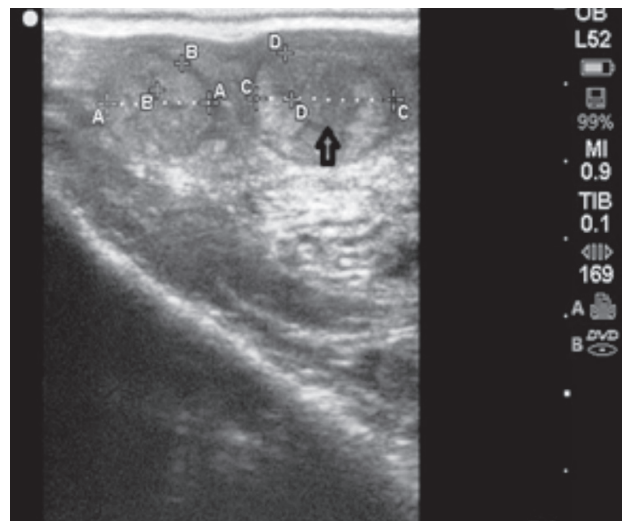

Fig. 3. Presence of $<1 \mathrm{~mm}$ of fluid in the uterine lumen (indicated by black arrow) on day 43 post-partum

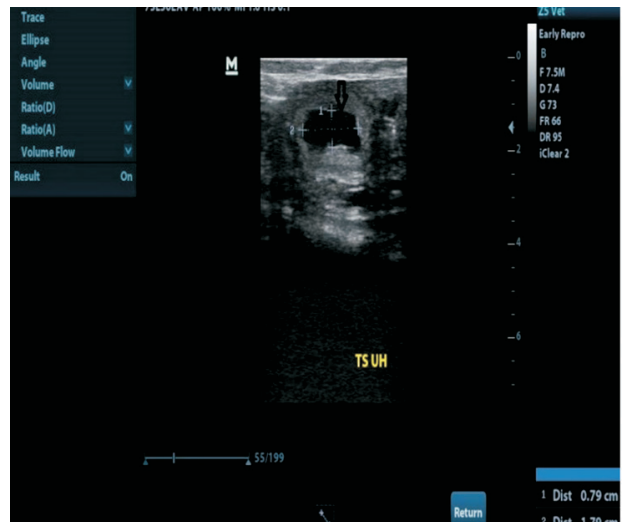

Fig. 5. Presence of 5-10 $\mathrm{mm}$ of fluid in the uterine lumen (anechoic area indicated by black arrow) on day 43 post-partum

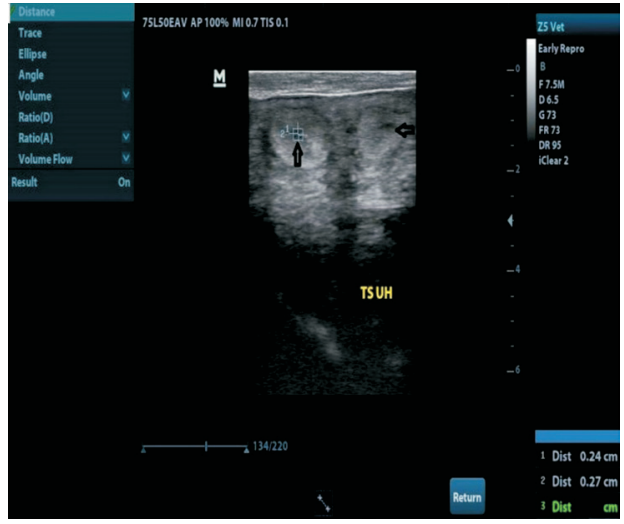

Fig. 4. Presence of $1-5 \mathrm{~mm}$ of fluid in the uterine lumen (anechoic area indicated by black arrow) on day 43 post-partum

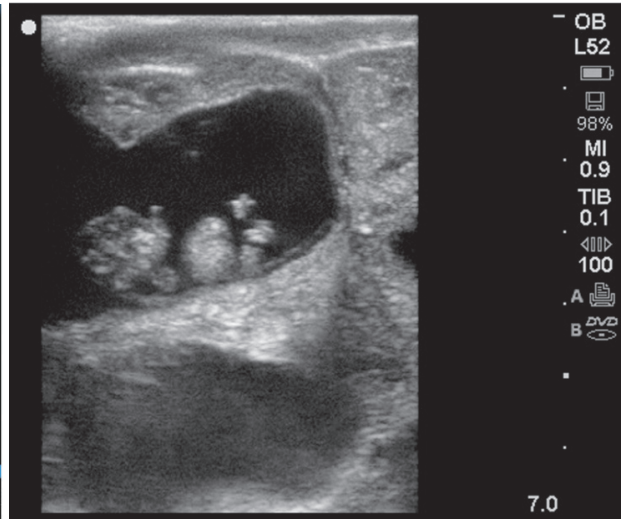

Fig. 6. Pregnancy confirmed 32 days after artificial insemination; Image showing embryo with head, hind limbs and genital tubercle 
A. Sharma and M. Singh: Establishing a relationship between endometrial cytology and uterine fluid in post-partum dairy cows

Statistical analysis. The data was statistically analyzed using one way ANOVA, and two-tailed $t$-test with SAS (Statistical Analysis Software), SAS ${ }^{\circledR}$ 9.2 TS Level version 2M2 for windows. The relationship between the amount of uterine fluid and PMN was examined by simple linear regression (Fig. 7).

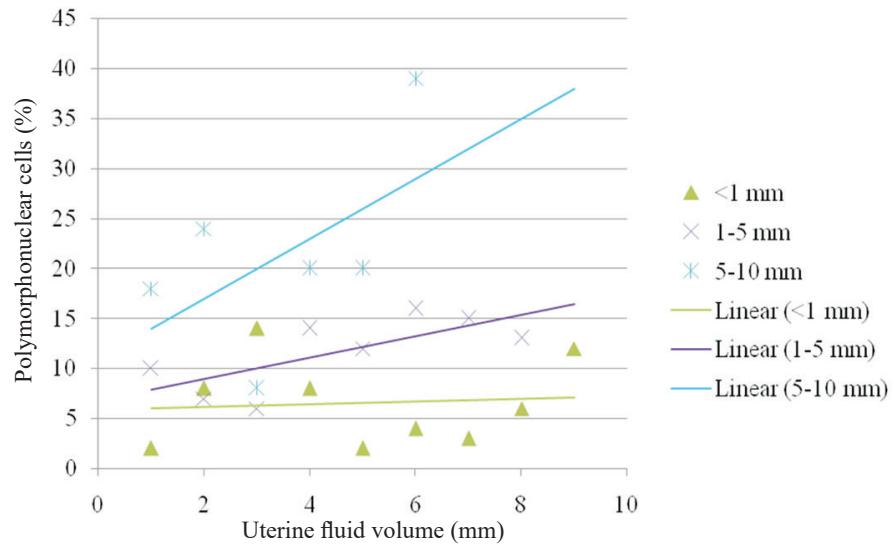

Fig. 7. Linear regression lines depicting a positive association between the amount of uterine fluid and PMN cells percentage

\section{Results and discussion}

The cytobrush technique was used successfully to obtain samples for EC in all 23 cows. Cows were distributed almost equally between the low $(<10 \%)$ and high PMN $(<10 \%)$ groups. 56\% (13 of 23 ) was the overall prevalence of sub-clinical endometritis (based on high PMNs) within the study population, and PMNs were not completely absent in any of the 23 cows. None of the cows developed obvious signs of clinical endometritis during the study.

Different thresholds of PMN (5\% to $>25 \%$ ), and different examination time frames (21-60 d post-partum) have been used to define sub-clinical endometritis (DOUREY et al., 2011). In brief, BARLUND et al. (2008) considered $>8 \%$ PMN as positive for endometritis when sampled between 28 and $41 \mathrm{~d}$ post-partum, whereas GILBERT et al. (2005), using the uterine lavage technique, reported that $>5 \%$ PMNs was an indicator of endometrial inflammatory response in cows sampled between 40 and $60 \mathrm{~d}$ post-partum. In the present study, the criterion of KASIMANICKAM et al. (2004), i.e. $>10 \%$ PMN between days 34-47 post-partum as indicative of sub-clinical endometritis, was adopted. 
A. Sharma and M. Singh: Establishing a relationship between endometrial cytology and uterine fluid in post-partum dairy cows

Ultrasonographic evaluation of the genitalia in the present study revealed that the time required for uterine involution was significantly shorter $(\mathrm{P}<0.01)$ in cows having low PMNs $(24.1 \pm 1.0 \mathrm{~d})$ when compared to cows having high PMNs $(31.7 \pm 0.9 \mathrm{~d})$. These findings were supported by the fact that cows having uterine fluid on the day of the EC were slow to involute $(30.0 \pm 1.2 \mathrm{~d})$ as compared to cows without uterine fluid $(25.8 \pm 1.7 \mathrm{~d})$. This outcome indicates two things: (1) a relationship between EC and uterine fluid in post-partum cows, (2) inflammation (presence of PMNs) during early post-partum period leads to delayed involution. However uterine involution was rapid in primiparous cows (29 d) as compared to multiparous cows (33.7 d) having high PMNs. Also, POYAM and TIWARI (2015) reported faster involution in primiparous cows. Contrarily, REKWOT et al. (2000) reported that uterine involution is rapid in multiparous cows.

Table 1. Days (Mean $\pm \mathrm{SE}$ ) taken to complete uterine involution and resumption of ovarian activity in post-partum cows diagnosed with different percent level of PMNs

\begin{tabular}{|l|c|c|c|}
\hline PMNs level (\%) & $\begin{array}{c}\text { Uterine } \\
\text { involution, days }\end{array}$ & $\begin{array}{c}\text { First post-partum } \\
\text { ovulation, days }\end{array}$ & $\begin{array}{c}\text { Number (\%) of cows ovulated within } \\
\text { 4 weeks post-partum }\end{array}$ \\
\hline $\begin{array}{l}\text { Low }(<10 \%) \\
(\mathrm{n}=10)\end{array}$ & $24.1 \pm 1.0^{\mathrm{x}}$ & $23.4 \pm 1.4^{\mathrm{a}}$ & $7(70 \%)$ \\
\hline $\begin{array}{l}\text { High }(>10 \%) \\
(\mathrm{n}=13)\end{array}$ & $31.7 \pm 0.9^{\mathrm{y}}$ & $30.1 \pm 1.3^{\mathrm{b}}$ & $2(15 \%)$ \\
\hline
\end{tabular}

a,b - Values with different superscripts within the same column are significantly different $(\mathrm{P}<0.05){ }^{\mathrm{x}, \mathrm{y}}$ - Values with different superscripts within the same column are significantly different $(\mathrm{P}<0.01)$

The calving to first ovulation interval was significantly shorter $(23.4 \pm 1.4$ vs. 30.1 $\pm 1.3 \mathrm{~d} ; \mathrm{P}<0.01)$ in cows with low PMN, than in those in the high PMN group. Also, a higher proportion of low PMN cows ovulated between 3-4 weeks post-partum (70\%; 7 of 10$)$ than high PMN cows (15\%; 2 of 13) (Table 1). Overall, 39\% (9/23) of cows ovulated before 4 weeks post-partum. On the basis of the presence of uterine fluid, the first ovulation post-partum was significantly earlier $(\mathrm{P}<0.05)$ in cows having no uterine fluid $(24.3 \pm 1.6 \mathrm{~d})$ as compared to cows having uterine fluid $(29 \pm 1.4 \mathrm{~d})$ on day 43 post-partum. Interaction between parity and PMN group was also analyzed, with primiparous cows in the high $\mathrm{PMN}$ group having a longer $(\mathrm{P}<0.01)$ mean interval to ovulation $(33.2 \pm 1.7 \mathrm{~d})$ than those in the low PMN group $(24.8 \pm 1.7 \mathrm{~d})$. Furthermore, the interval to ovulation in multiparous cows in the high PMN group was significantly longer $(\mathrm{P}<0.05)$ as compared to cows in the low PMN group $(28.1$ \pm 1.6 and $22 \pm 2.2 \mathrm{~d}$, respectively). Thus, a high presence of PMN was detrimental to primiparous cows, as these cows have a $5 \mathrm{~d}$ longer interval to ovulation as compared to multiparous cows. In support of our findings, DOUREY et al. (2011) also reported an 11 day longer interval to ovulation in primiparous cows having higher PMN cells 
A. Sharma and M. Singh: Establishing a relationship between endometrial cytology and uterine fluid in post-partum dairy cows

on day 25 post-partum. Contrarily, GILBERT et al. (2005) found no effect of parity on the prevalence of sub-clinical endometritis diagnosed via uterine lavage between days 40 and 60 post-partum.

Neutrophils form the first line of increased post-partum defense against invading pathogenic organisms, resulting in large neutrophil populations within the uterine lumen. The phagocytic activity of neutrophils helps in halting the propagation and establishment of bacterial infection in the post-partum uterus (BARLUND et al., 2008). The occurrence of uterine infections is reduced under estrogenic influence (LEWIS, 1997). So, an early resumption of ovarian activity in cows with low PMN, and the associated increase in estradiol concentrations can enable the inherent defense mechanisms to eliminate the uterine contaminants early (DOUREY et al., 2011). An equivocal strong association between increased estrogen concentrations and leukocyte migration to the uterus in cattle has been reported, so, the possibility of increased leukocyte infiltration in low PMN cows during the early post-partum period may favor the rapid clearance of the inflammatory reaction (SUBANDRIO et al., 2000). Cows with high $(>10 \%)$ PMN had delayed restoration of ovarian cyclicity, which could be due to sub-clinical endometritis and delayed uterine involution.

During the early post-partum period, uterine infection inhibits estradiol production from aromatization of androgens, and, thus, leads to alterations in the lifespan of the follicle at recruitment and selection, and consequently ovulation (WILLIAMS et al., 2007). Also, uterine infections suppress pituitary LH secretion and perturb postpartum ovarian follicular growth and function, which disrupts ovulation in cattle (SHELDON et al., 2002). GILBERT et al. (2005) reported a severe reduction in first service conception rates in cows affected with sub-clinical endometritis. However, there was no significant difference between low and high PMN groups in the first service conception rates during the present investigation (both 21\%). In the present study, all 23 cows were followed until pregnancy was confirmed. GILBERT et al. (2005) conducted a study in which cows were inseminated at detected estrus, similar to the present investigation. SCE has been associated with an increase in days open and lower conception rates in cows (SHELDON and DOBSON, 2004). This may be due to suboptimal conditions for sperm transportation and storage, oocyte maturation and ovulation, zygote development, implantation and embryonic and fetal growth (GILBERT, 2011). SCE is a highly prevalent disease having no clinical symptoms but it significantly impairs the fertility of dairy cows (SHELDON et al., 2006).

In the present study, a relationship between the quantity of uterine fluid and PMN has been drawn, as with the increase in PMN population, the quantity of uterine fluid also increased (Fig. 7). Mean PMN in cows with no uterine fluid $(<1 \mathrm{~mm})$, with a small volume $(1-5 \mathrm{~mm})$, and in those with a high volume $(5-10 \mathrm{~mm})$ of uterine fluid were $6 \%$, 
A. Sharma and M. Singh: Establishing a relationship between endometrial cytology and uterine fluid in post-partum dairy cows

$11 \%$ and $21 \%$, respectively ( $6 v s .21, \mathrm{P}<0.05$ - between no uterine fluid and high volume uterine fluid, Fig. 8). Eleven (78\%) of the 14 cows with uterine fluid had high PMN, whereas only two (22\%) of the 9 cows with no uterine fluid had high PMN. So, 13 cows with high PMN were considered, and $11(84 \%)$ had uterine fluid. These findings were similar to the data recorded by DOUREY et al. (2011). KASIMANICKAM et al. (2004) also suggested that measuring uterine fluid volume and endometrial thickness may be helpful in diagnosing the inflammatory process. Uterine fluid volume, identified using ultrasonography after the third week post-partum, was positively correlated with uterine swab bacterial growth (MATEUS et al., 2002).



Fig. 8. Percent increase in the PMN cells with change in uterine fluid volume

There were reported to be two populations of cows with endometritis: cows that had a cellular inflammatory response but little or no fluid accumulation and cows that had fluid accumulation with minimal concentration of PMN (BARLUND et al., 2008). In the present study, similar populations of cows were found; however, cows with higher quantities of fluid also had higher PMN concentrations.

As a positive relationship between uterine fluid and PMN concentration was detected, there also was a relationship between the presence of uterine fluid, uterine involution and the interval from calving to first ovulation. The mean intervals to first ovulation in cows with and without uterine fluid were $29 \pm 1.5$ and $24.3 \pm 1.6 \mathrm{~d}$, respectively $(\mathrm{P}<0.05)$. Contrarily, DOUREY et al. (2011) reported no significant relationship between uterine fluid and the calving to first ovulation interval. Furthermore, cows that had uterine fluid on day 43 post-partum had fewer $(\mathrm{P}<0.01)$ days open $(107.1 \pm 4.1)$ than those that had no uterine fluid $(130.3 \pm 5.9)$, suggesting that the presence of uterine fluid on day 43 postpartum may be an indicator of early recovery. This is further supported by our finding that 7 of the $14(50 \%)$ cows diagnosed with uterine fluid conceived on the first insemination, compared to only three of $9(33 \%)$ that had no uterine fluid (Table 2). So, the presence 
A. Sharma and M. Singh: Establishing a relationship between endometrial cytology and uterine fluid in post-partum dairy cows

of uterine fluid in the $6^{\text {th }}$ week post-partum indicates an active inflammatory process as evidenced by increased PMN (DOUREY et al., 2011) and an inference may be drawn that these cows overcame the uterine inflammation more readily, resulting in a shorter interval from calving to conception.

Table 2. Days (Mean \pm SE) taken to complete uterine involution and resumption of ovarian activity in post-partum cows on the basis of the absence or presence of uterine fluid during transrectal ultrasonography

\begin{tabular}{|l|c|c|c|}
\hline Uterine fluid & $\begin{array}{c}\text { First post-partum } \\
\text { ovulation }\end{array}$ & Days open & $\begin{array}{c}\text { Number (\%) of cows having high PMN } \\
\text { conceived on first insemination post-partum }\end{array}$ \\
\hline $\begin{array}{l}\text { Absent } \\
(\mathrm{n}=9)\end{array}$ & $24.3 \pm 1.6^{\mathrm{a}}$ & $130.3 \pm 5.9^{\mathrm{y}}$ & $3(33 \%)$ \\
\hline $\begin{array}{l}\text { Present } \\
(\mathrm{n}=14)\end{array}$ & $29.0 \pm 1.4^{\mathrm{b}}$ & $107.1 \pm 4.1^{\mathrm{x}}$ & $7(50 \%)$ \\
\hline
\end{tabular}

$a, b$ Values with different superscripts within the same column are significantly different $(\mathrm{P}<0.05),{ }^{\mathrm{x}, \mathrm{y}}$ Values with different superscripts within the same column are significantly different $(\mathrm{P}<0.01)$

The present study has, thus, established a relationship between uterine fluid volume (determined by ultrasonography) and PMN concentration. However, luminal diameter measurement for uterine fluid could never be precise, because the positioning of the transducer on the uterus and could influence the result (BARLUND et al., 2008).

In conclusion, the interval from calving to first ovulation was $7 \mathrm{~d}$ shorter for cows that had low $(<10 \%)$ PMN on EC performed on day 43 post-partum. Primiparous cows with high $(>10 \%)$ PMN on day 43 post-partum had the longest interval to first ovulation. Conception rates to first insemination were not affected by the relative proportion of PMN in EC. Although a greater proportion of cows with uterine fluid conceived on the first insemination, an increased volume of uterine fluid was indicative of high PMN. As we all know transrectal ultrasonography is a practical cow-side application, but it cannot be used alone to correctly diagnose sub-clinical endometritis during the post-partum period. Therefore, combining transrectal ultrasonography with endometrial cytology on day 43 post-partum has tremendous diagnostic value in the assessment of uterine inflammation.

\section{Acknowledgements}

I would like to thank Dr. Madhumeet Singh for the precious and timely guidance which helped me in the completing my research work. This research did not receive any specific grant from funding agencies in the public, commercial, or not-for-profit sectors. 
A. Sharma and M. Singh: Establishing a relationship between endometrial cytology and uterine fluid in post-partum dairy cows

\section{References}

ABDEL-KHALEK, A. E., M. A. EL-HARRAIRY, A. F. MEHREZ, W. F. M. FOUAD (2013): Uterine involution and reproductive performance of lactating friesian cows treated with oxytocin and prostaglandin (PGF2 $\alpha$ ) at calving. J. Anim. Poul. Prod. 4, 349-362.

BARLUND, T. D., T. D. CARRUTHERS, C. L. WALDNER, C. W. PALMER (2008): A comparison of diagnostic techniques for postpartum endometritis in dairy cows. Theriogenology 69, 714723.

DOI: 10.1016/j.theriogenology.2007.12.005

BUTT, B. M., P. L. SENGER, P. R. WIDDERS (1993): Neutrophil migration in the bovine uterine lumen following intrauterine inoculation with killed Haemophilus somnus. J. Reprod. Fertil. 93, 341-345.

DOI: $10.1530 /$ jrf.0.0930341

DOUREY, A., M. G. COLAZO, P. P. BARAJAS, D. J. AMBROSE (2011): Relationships between endometrial cytology and interval to first ovulation, andpregnancy in postpartum dairy cows in a single herd. Res. Vet. Sci. 91, 149-153.

DOI: 10.1016/j.rvsc.2010.11.011

FOLDI, J., M. KULKSAR, A. PECSI, J. A. C. M. LOHUIS (2006): Bacterial complications of postpartum uterine involution in cattle. Anim. Reprod. Sci. 96, 265-281.

DOI: 10.1016/j.anireprosci.2006.08.006

GILBERT, R. O. (2011): The effect of endometritis on the establishment of pregnancy in cattle. Reprod. Fertil. Dev. 24, 252-257.

DOI: $10.1071 /$ rd11915

GILBERT, R. O., S. T. SHINGUARD, H. N. ERB, M. FRAJBLAT (2005): Prevalence of endometritis and its effect on reproductive performance of dairy cows. Theriogenology 64, 1879-1888.

DOI: $10.1016 /$ j.theriogenology.2005.04.022

KASIMANICKAM, R., T. F. DUFFIELD, R. A. FOSTER, C. J. GARTLEY, K. E. LESLIE, J. S. WALTON, W. H. JOHNSON (2004): Endometrial cytology and ultrasonography for thedetection of sub-clinical endometritis in postpartum dairy cows. Theriogenology 62, 9-23.

DOI: 10.1016/j.theriogenology.2003.03.001

KLUCINSKI, W., S. P. TARGOWSKI, E. MIERNIK DEGORSKA, A. WINNICKER (1990): The phagocytic activity of polymorphonuclear leucocytes isolated from normaluterus and that with experimentally induced inflammation in cows. Vet. Med. Abst. 37, 506-512.

DOI: 10.1111/j.1439-0442.1990.tb00937.x

LE BLANC, S. J., T. F. DUfFIELD, K. E. LESLIE, K. G. BATEMAN, G. P. KEEFE, J. S. WALTON (2002): Defining and diagnosing post partum clinical endometritis and its impact on reproductive performance in dairy cows. J. Dairy Sci. 85, 2223-2236.

DOI: $10.3168 /$ jds.s0022-0302(02)74302-6 
A. Sharma and M. Singh: Establishing a relationship between endometrial cytology and uterine fluid in post-partum dairy cows

LEWIS, G. S. (1997): Uterine health and disorders. J. Dairy Sci. 80, 984-994.

MATEUS, L., L. LOPES DA COSTA, J. BERNARDO SILVA (2002): Influence of puerperal uterine infection on uterine involution and postpartum ovarian activity in dairy cows. Reprod. Domest. Anim. 37, 31-35.

DOI: $10.1046 / \mathrm{j} .1439-0531.2002 .00317 . \mathrm{x}$

OPSOMER, G., Y. T. GROHN, J. HERTL, M. CORYN, H. DELUYKER, A. DE KRUIF (2000): Risk factors for postpartum overian dysfunction in high producing cows in Belgium: a field study. Theriogenology 53, 841-857.

DOI: $10.1016 / \mathrm{s} 0093-691 \mathrm{x}(00) 00234-\mathrm{x}$

PATEL, P. M., A. J. DHAMI, T. V. HINSU, V. P. RAMAMI, N. P. SARVAIYA, F. S. KAVANI (2006): Comparative evaluation of blood biochemical and progesterone profile of fertile and infertile estrous cycles in postpartum Holstein Friesian cows. Indian J. Anim. Sci. 76, 191-195.

POYAM, M. R., R. P. TIWARI (2015): Ultrasonographic image of uterine involution in postpartum sahiwal cows. Indian J. Anim. Reprod. 36, 57-59.

REKWOT, P. I., D. OGWU, E. O. OYEDIPE (2000): Influence of bull biostimulation, season and parity on resumption of ovarian activity of Zebu (Bos indicus) cattle following parturition. Anim. Reprod. Sci. 63, 1-11.

DOI: $10.1016 / \mathrm{s} 0378-4320(00) 00163-9$

SENOSY, W. S., M. UCHIZA, N. TAMEOKA, Y. IZAIKE, T. OSAWA (2009): Association between evaluation of the reproductive tract by various diagnostic tests andrestoration of ovarian cyclicity in high-producing dairy cows. Theriogenology 72, 1153-1162.

DOI: $10.1016 /$ j.theriogenology.2009.07.007

SHELDON, I. M., H. DOBSON (2004): Postpartum uterine health in cattle. Anim. Reprod. Sci. 82/83, 295-306.

DOI: $10.1016 /$ j.anireprosci.2004.04.006

SHELDON, I. M., G. S. LEWIS, S. LEBLANC, R. O. GILBERT (2006): Defining postpartum uterine disease in cattle. Theriogenology 65, 1516-1530.

DOI: $10.1016 /$ j.theriogenology.2005.08.021

SHELDON, I. M., D. E. NOAKES, A. N. RYCROFT, D. U. PFEIFFER, H. DOBSON (2002): Influence of uterine bacterial contamination after parturition on ovarian dominantfollicle selection and follicle growth and function in cattle. Reproduction 123, 837-845.

DOI: $10.1530 /$ rep.0.1230837

SUBANDRIO, A. L., I. M. SHELDON, D. E. NOAKES (2000): Peripheral and intrauterine neutrophil function in the cow: the influence of endogenous and exogenous sexsteroid hormones. Theriogenology 53, 1591-1608.

DOI: $10.1016 / \mathrm{s} 0093-691 \times(00) 00300-9$

WILliAMS, E. J., D. P. FISHER, D. E. NOAKES, G. C. W. ENGLAND, A. RYERAFT, H. DOBSON, I. M. SHELDON (2007): The relationship between uterine pathogen growth 
A. Sharma and M. Singh: Establishing a relationship between endometrial cytology and uterine fluid in post-partum dairy cows

density and ovarian function in the postpartum dairy cows. Theriogenology 68, 549-559.

DOI: $10.1016 /$ j.theriogenology.2007.04.056

Received: 19 March 2018

Accepted: 11 June 2019

\section{SHARMA, A., M. SINGH: Utvrđivanje odnosa između citologije endometrija i maternične tekućine i procjena njihove povezanosti s pokazateljima plodnosti u mliječnih krava poslije teljenja. Vet. arhiv 89, 435-446, 2019.}

\section{SAŽETAK}

Cilj ovoga rada bio je istražiti odnos između maternične tekućine i citologije endometrija (EC) te povezanost s involucijom maternice, vremenom od teljenja do prve ovulacije i koncepcijom u mliječnih krava. Četrdeset i tri dana poslije teljenja 23 mliječne krave svrstane su u skupine s obzirom na to imaju li mali broj (manje od $10 \%$ ) ili veliki broj (više od $10 \%$ ) polimorfonuklearnih stanica (PMN), dok je količina maternične tekućine procijenjena ultrazvukom. Do involucije maternice došlo je znakovito ranije u krava s malim broj PMN-a u usporedbi s onima s velikim brojem PMN-a (24,1 prema 31,7 dana). Vrijeme od teljenja do prve ovulacije bilo je znakovito kraće u krava s malim brojem PMN-a u usporedbi s onima s velikim brojem PMN-a (23,4 prema 30,7 dana). S porastom količine maternične tekućine porastao je i PMN, sa $6 \%$ na $21 \%$. Prosječno vrijeme od teljenja do ovulacije bilo je dulje u prvotelki s velikim brojem PMN-a (33 dana) u usporedbi s prvotelkama (24 dana) i starijim grlima (22 dana) s malim brojem PMN-a. Krave koje su imale materničnu tekućinu 43. dan poslije teljenja imale su nekoliko dana kraći puerperij od onih bez maternične tekućine (107 prema 130 dana). Možemo zaključiti da transrektalni ultrazvuk zajedno s citologijom endometrija 43. dan poslije teljenja ima dijagnostičku vrijednost u procjeni upale maternice.

Ključne riječi: citologija endometrija; plodnost; polimorfonuklearne stanice; transrektalni ultrazvuk; maternična tekućina 